\title{
ARTERIAL HYPERTENSION ASSOCIATED WITH HYPERURICEMIA: FEATURES OF HEART DAMAGE
}

DOI: 10.36740/WLek202005119

\author{
Olha M. Chernatska, Liudmyla N. Prystupa, Hanna A. Fadieieva, Alina V. Liashenko, Yuliia O. Smiianova \\ INTERNAL MEDICINE DEPARTMENT, MEDICAL INSTITUTE, SUMY STATE UNIVERSITY, SUMY, UKRAINE
}

\begin{abstract}
The aim is the analysis of hyperuricemia influence on the heart features in patients with arterial hypertension.

Materials and methods: We include 75 patients with arterial hypertension which were divided in two groups according to the level of uric acid in the blood, 30 practically healthy people. Patients from the I group $(n=40)$ had arterial hypertension and coexistent hyperuricemia; $I I(n=35)$ - arterial hypertension. Left ventricular mass index was determined for left ventricular hypertrophy confirmation.

We used clinical, anthropometric, biochemical, instrumental, statistical method. Serum uric acid level was observed by the reaction with uricase. Left ventricular mass index was calculated as left ventricular mass to body surface area ratio. The results were analyzed statistically by SPSS 21 and Graphpad.

Results: Left ventricular mass index was significantly higher $(p=0,0498)$ in patients from the I group $(109,7 \pm 3,21) \mathrm{g} / \mathrm{m}^{2}$ comparable with the II $(97,6 \pm 5,35) \mathrm{g} / \mathrm{m}^{2}$ and increased in proportion to the biggest level of uric acid $(r=0,31 ; p=0,04)$ in patients with arterial hypertension and hyperuricemia.

Conclusions: Concentric and excentric left ventricular hypertrophy, increased left ventricular mass index proportionally to uric acid levels $(r=0,31 ; p=0,04)$ is the confirmation of important role of hyperuricemia in the left ventricular hypertrophy development in patients with arterial hypertension.
\end{abstract}

KEY WORDS: arterial hypertension, hyperuricemia, left ventricular mass index

Wiad Lek. 2020;73(5):943-946

\section{INTRODUCTION}

A new wave of the interest in hyperuricemia is associated not only with the significant role of uric acid level elevation as an independent and modifiable risk factor of gout but also as an indicator of cardiovascular and chronic kidney disease (CKD) [1].

Hyperuricemia is determined in $26 \%$ of patients with arterial hypertension $(\mathrm{AH})$. The increased uric acid level is associated with decline control of blood pressure (BP) [2].

Hyperuricemia leads to the kidney function disorders. It is connected with the adhesion of sodium monourate crystals on the surface of kidney epithelial cells followed by activation of inflammatory mechanisms [3].

On the other hand, a lot of publications are devoted to the effects of hyperuricemia on cardiac function disorders. The high levels of free radicals which are results of uric acid synthesis and progressive endothelial dysfunction leads to the heart failure. It is associates with the reduction of myocardium perfusion, increase of vascular tonus, decrease of the blood flow in the coronary arteries. All these mechanisms lead to the myocardium contractile dysfunction [2].

Relaxation of the myocardium is changed at first during AH. Left ventricular (LV) hypertrophy is determined as a criterion of heart disorders in patients with $\mathrm{AH}$ [4] and one of the indicators of heart failure with reserved ejection fraction [5]. Hyperuricemia is associated with the increased risk of LV hypertrophy on $75 \%$ [6]. In conclusion, the assessment of relationship between hyperuricemia and LV hypertrophy is important nowadays.
As a result the actual internal medicine problem is the determination of increased uric acid level influence on the severity of heart and kidney disorders in hypertensive patients.

\section{THE AIM}

The aim is the analysis of hyperuricemia influence on the features of heart damage in patients with arterial hypertension. Study had aim to estimate the LV geometry in patients with $\mathrm{AH}$ and coexistent hyperuricemia; to define the influence of increased uric acid levels on the LV hypertrophy progress by the detail analysis of relationship between hyperuricemia and LV mass index (LVMI) in hypertensive patients.

\section{MATERIALS AND METHODS}

We observed 75 patients with AH in the clinical trial treated in Sumy Central Regional Clinical Hospital during 20182019 years and 30 practically healthy people. They were divided in two groups according to the level of uric acid in the blood. Patients from the I group $(n=40)$ had $\mathrm{AH}$ and coexistent hyperuricemia; II $(n=35)-\mathrm{AH}$.

Patients were enrolled in the study after informed consent obtained in accordance with the Helsinki Declaration of the World Medical Association on the Ethical Principles of Scientific and Medical Research. The study was approved 
by the Bioethics Committee for experimental and clinical studies at Sumy State University Medical Institute.

The diagnosis, the stage, the degree of $\mathrm{AH}$ were confirmed according to the Unified clinical guidelines of primary, emergency and secondary care of arterial hypertension (2016) developed by the working group of the Ministry of Health of Ukraine [7] and guidelines of Ministry of Health of Ukraine №384 (24.05.2012 year) [8]. Hyperuricemia was determined by European League Against Rheumatism (EULAR, 2016 p.) if the uric acid level was more than $360 \mathrm{mcmol} / \mathrm{l}$ (6 mg/dl) [9]. Asymptomatic hyperuricemia was the coexistent pathology in hypertensive patients.

LV hypertrophy is the objective feature of heart damage for patients with $\mathrm{AH}$ [7]. The indicators were analyzed in hypertensive persons with and without hyperuricemia.

We observed patients with written consent of participation in our study, presence of confirmed $\mathrm{AH}$ and coexistent hyperuricemia or $\mathrm{AH}$ without increased uric acid levels.

The clinical characteristic of patients is presented in table I.

All observed patients were comparable by age with predominance of men.

The significant difference between the level of systolic and diastolic BP were absent in patients from the I and II group $(\mathrm{p}=0,8467 ; \mathrm{p}=0,9171)$.
The duration of $\mathrm{AH}$ was respectively $(4,3 \pm 2,31)$ and $(4,0$ $\pm 2,11)$ year $(\mathrm{p}=0,9247)$ for patients with $\mathrm{AH}$ and coexistent hyperuricemia comparable with hypertensive persons.

Firstly we determined $\mathrm{AH}$ in all persons with comorbidity. Hyperuricemia was the coexistent pathology.

We collected anamnesis, made the objective and physical examination of all participants.

Measurement of height $(\mathrm{m})$ was made by centimeter tape; weight $(\mathrm{kg})$ - by electronic scales. Body surface area was calculated by Mosteller formula as square root of the height $(\mathrm{cm})$ multiplied by the weight $(\mathrm{kg})$ divided by 3600 [10].

Serum uric acid level was observed by enzymatic photocolorimetry. The biggest level of uricemia is associated with increased the color intensity of the product resulted by the reaction with uricase [11].

The echocardiography was done. LVMI was calculated as a LV mass $(\mathrm{LVM})(\mathrm{g})$ to body surface area $\left(\mathrm{m}^{2}\right)$ ratio [12].

LVM was calculated according to the American Society of Echocardiography's Guidelines:

$\operatorname{LVM}(\mathrm{g})=0,8 \cdot\left\{1,04 \cdot\left[\left(\mathrm{LVIDd}+\mathrm{LVPWT}+\mathrm{IVSTd}^{3}-\right.\right.\right.$ $\left.\left.(\text { LVIDd })^{3}\right]\right\}+0,6$ [27]. We estimated LV internal dimension at end diastole (LVIDd), LV posterior wall thickness at end diastole (LVPWTd), intraventricular septal thickness at end diastole (IVSTd).

Table I. Clinical characteristic of all observed patients

\begin{tabular}{|c|c|c|c|c|}
\hline Indicator & $\begin{array}{l}\text { I group } \\
(n=40)\end{array}$ & $\begin{array}{l}\text { II group } \\
(n=35)\end{array}$ & $\begin{array}{l}\text { control } \\
(n=30)\end{array}$ & $\mathbf{p}$ \\
\hline age (years) & $52,4 \pm 0,69$ & $54,1 \pm 0,61$ & $53,3 \pm 0,4$ & $\begin{array}{l}\mathrm{p}_{1}=0,0725 \\
\mathrm{p}_{2}=0,3045 \\
\mathrm{p}_{3}=0,2941\end{array}$ \\
\hline \multirow[t]{2}{*}{ gender } & $27(70 \%)$ & $24(68,6 \%)$ & $21(70 \%)$ & \\
\hline & $13(30 \%)$ & $11(31,4 \%)$ & $9(30 \%)$ & \\
\hline Systolic BP (mmHg) & $146,4 \pm 5,38$ & $144,7 \pm 7,07$ & $120,8 \pm 6,48$ & $\begin{array}{l}\mathrm{p}_{1}=0,8467 \\
\mathrm{p}_{2}=0,0032 \\
\mathrm{p}_{3}=0,0166\end{array}$ \\
\hline Diastolic BP (mmHg) & $94,8 \pm 6,05$ & $93,9 \pm 5,93$ & $80,1 \pm 2,6$ & $\begin{array}{l}\mathrm{p}_{1}=0,9162 \\
\mathrm{p}_{2}=0,0495 \\
\mathrm{p}_{3}=0,0482\end{array}$ \\
\hline Uricemia (mcmol/l) & $401,6 \pm 3,93$ & $304,5 \pm 4,95$ & $265,0 \pm 8,38$ & $\begin{array}{l}\mathrm{p}_{1}<0,0001 \\
\mathrm{p}_{2}<0,0001 \\
\mathrm{p}_{3}<0,0001\end{array}$ \\
\hline Duration of $\mathrm{AH}$ (years) & $4,3 \pm 2,31$ & $4,0 \pm 2,11$ & - & $p_{1}=0,9247$ \\
\hline $\begin{array}{c}\text { Duration of hyperuricemia } \\
\text { (years) }\end{array}$ & $4,1 \pm 0,35$ & - & - & - \\
\hline Glucose in blood, mmol/l & $4,4 \pm 0,7$ & $4,3 \pm 0,59$ & $4,04 \pm 0,53$ & $\begin{array}{l}\mathrm{p}_{1}=0,9147 \\
\mathrm{p}_{2}=0,7000 \\
\mathrm{p}_{3}=0,7476\end{array}$ \\
\hline
\end{tabular}

\section{Notes:}

1. $p_{1}$ - the significance of differences between the indicators of the I and II groups;

2. $p_{2}$ - the significance of differences between the indicators of the I group and control;

3. $p_{3}$ - the significance of differences between the indicators of the II group and control;

4. $n$ - the number of persons;

5. f- female;

6. $\mathrm{m}$ - male 
Table II. Echocardiographic indicators, which are necessary for left ventricular mass index calculation

\begin{tabular}{|c|c|c|c|c|}
\hline Indicator & $\begin{array}{l}\text { I group } \\
(n=40)\end{array}$ & $\begin{array}{l}\text { Il group } \\
(n=35)\end{array}$ & $\begin{array}{l}\text { control } \\
(n=30)\end{array}$ & $\mathbf{p}$ \\
\hline $\begin{array}{l}\text { Left ventricular internal dimension at end } \\
\qquad \text { diastole, } \mathrm{cm}\end{array}$ & $4,9 \pm 0,06$ & $4,7 \pm 0,1$ & $4,6 \pm 0,04$ & $\begin{array}{l}\mathrm{p}_{1}=0,0819 \\
\mathrm{p}_{2}=0,0002 \\
\mathrm{p}_{3}=0,3849\end{array}$ \\
\hline $\begin{array}{l}\text { left ventricular posterior wall thickness at } \\
\text { end diastole, } \mathrm{cm}\end{array}$ & $1,1 \pm 0,02$ & $1,04 \pm 0,02$ & $0,81 \pm 0,02$ & $\begin{array}{l}\mathrm{p}_{1}=0,0381 \\
\mathrm{p}_{2}<0,0001 \\
\mathrm{p}_{3}<0,0001\end{array}$ \\
\hline $\begin{array}{l}\text { intraventricular septal thickness at end } \\
\text { diastole, } \mathrm{cm}\end{array}$ & $1,1 \pm 0,02$ & $1,02 \pm 0,04$ & $0,78 \pm 0,01$ & $\begin{array}{l}\mathrm{p}_{1}=0,0673 \\
\mathrm{p}_{2}<0,0001 \\
\mathrm{p}_{3}<0,0001\end{array}$ \\
\hline left ventricular mass, $\mathrm{g}$ & $205,2 \pm 5,41$ & $175,9 \pm 9,02$ & $117,8 \pm 2,72$ & $\begin{array}{l}\mathrm{p}_{1}=0,0054 \\
\mathrm{p}_{2}<0,0001 \\
\mathrm{p}_{3}<0,0001\end{array}$ \\
\hline weight, kg & $75,9 \pm 1,79$ & $69,9 \pm 1,4$ & $60,2 \pm 0,1$ & $\begin{array}{l}\mathrm{p}_{1}=0,0117 \\
\mathrm{p}_{2}<0,0001 \\
\mathrm{p}_{3}<0,0001\end{array}$ \\
\hline height, $\mathrm{cm}$ & $169,1 \pm 0,01$ & $170,6 \pm 0,01$ & $163,3 \pm 0,01$ & $\begin{array}{l}\mathrm{p}_{1}<0,0001 \\
\mathrm{p}_{2}<0,0001 \\
\mathrm{p}_{3}<0,0001\end{array}$ \\
\hline body surface area, $\mathrm{kg} / \mathrm{m}^{2}$ & $1,9 \pm 0,02$ & $1,8 \pm 0,02$ & $1,7 \pm 0,02$ & $\begin{array}{l}\mathrm{p}_{1}<0,0001 \\
\mathrm{p}_{2}<0,0001 \\
\mathrm{p}_{3}=0,0008\end{array}$ \\
\hline left ventricular mass index, $\mathrm{g} / \mathrm{m}^{2}$ & $109,7 \pm 3,21$ & $97,6 \pm 5,35$ & $71,4 \pm 1,6$ & $\begin{array}{l}\mathrm{p}_{1}=0,0498 \\
\mathrm{p}_{2}<0,0001 \\
\mathrm{p}_{3}<0,0001\end{array}$ \\
\hline
\end{tabular}

Notes:

1. $p_{1}$ - the significance of differences between the indicators of the I and II groups;

2. $p_{2}$ - the significance of differences between the indicators of the I group and control;

3. $p_{3}$ - the significance of differences between the indicators of the II group and control;

4. $n$ - number of persons

LV hypertrophy was determined if the LVMI was more then $115 \mathrm{~g} / \mathrm{m}^{2}$ for men and $95 \mathrm{~g} / \mathrm{m}^{2}$ for women [5].

The hypothesis of normal samples distribution was tested by Kolmagorov-Smirnov criterion used SPSS 21.

If there was no reason for rejection of hypothesis about normal distribution law, the significance of the difference between the mean values was analyzed by Student's t-test for independent samples with the help of GraphPad.

This research was adopted by the Ethics Committee of Sumy State University, Sumy, Ukraine. Research was conducted keeping to the main issues of the Convention of the Council of Europe on Human Rights and Biomedicine of Declaration of Helsinki of the World Medical Association on the ethical principles of conducting medical research involving human beings (1975, with further amendments, including version of 2000) and Order of Ukrainian Ministry of Health № 690 on 23.09.2009.

\section{RESULTS AND DISCUSSION}

LV hypertrophy is the marker of heart disorders in hypertensive persons. LVMI was calculated in all observed patients. Indicators, which are necessary for this calculation, performed in table II.
LVMI was significantly higher $(\mathrm{p}=0,0498)$ in patients from the I group $(109,7 \pm 3,21) \mathrm{g} / \mathrm{m}^{2}$ comparable with the II $(97,6$ $\pm 5,35) \mathrm{g} / \mathrm{m}^{2}$.

There was the absence of significant relationship between uricemia and LVMI in persons from II group. LVMI increased in proportion to the biggest level of uricemia $(r=0,31 ; p=0,04)$ in the I group.

The analysis of LV geometry in patients from the I group showed the confirmation of concentric remodeling in $14(35 \%)$ persons, concentric hypertrophy - in 16 (40\%), excentric hypertrophy - in 7 (17,5\%), normal sizes - in 3 (7,5\%). The analysis of LV geometry in patients from the II group showed the confirmation of concentric remodeling in $20(57,14 \%)$ persons, concentric hypertrophy - in $4(11,43 \%)$, excentric hypertrophy - in $5(14,29 \%)$, normal sizes - in $6(17,14 \%)$.

The level of uric acid in patients with concentric remodeling was $(397,7 \pm 23,22) \mathrm{mcmol} / 1$; concentric hypertrophy - $(407,5$ $\pm 29,7) \mathrm{mcmol} / \mathrm{l}, \mathrm{p}=0,8$; excentric hypertrophy - $(401,0 \pm$ $20,66) \mathrm{mcmol} / \mathrm{l}, \mathrm{p}=0,9283$. The significant difference between uricemia in coexistent patients from the I group with concentric and excentric hypertrophy $(\mathrm{p}=0,8922)$.

LVMI increased in proportion to the biggest level of uricemia $(r=0,31 ; p=0,04)$ in the I group. Other investigators had similar results connected with positive correlation be- 
tween uricemia and LVMI in patients with $\mathrm{AH}(\mathrm{r}=0,346$, $\mathrm{p}<0,001)$ [13].

Finally, concentric and excentric hypertrophy were observed often in patients with $\mathrm{AH}$ and coexistent hyperuricemia. Furthermore normal type of LV geometry was present more often in hypertensive persons from the II group.

The significant difference between uricemia in coexistent patients from the I group with concentric and excentric hypertrophy. It means that hyperuricemia is associated with all types of LV hypertrophy.

\section{CONCLUSIONS}

1. Concentric and excentric left ventricular hypertrophy was determined often in patients with arterial hypertension which have increased uric acid levels. Concentric remodeling and normal type of left ventricular geometry were observed more often in hypertensive persons without hyperuricemia.

2. The significantly increased left ventricular mass index proportionally to uric acid levels $(\mathrm{r}=0,31 ; \mathrm{p}=0,04)$ is the confirmation of important role of hyperuricemia in the left ventricular hypertrophy development in patients with arterial hypertension.

\section{REFERENCES}

1. Tronko M.D., Dolzhenko M.N., Kushnirenko S.V. et al. Hiperurykemiia - nezalezhnyi faktor prohresuvannia khronichnoi khvoroby nyrok [Hyperuricemia - an independent factor for the progression of chronic kidney disease]. Kidneys. 2017; 6:94-98. doi: 10.22141/23071257.6.2.2017.102787. (UA)

2. Shuba N.M., Voronova T.D., Litvinenko S.V. Rol hyperurykemyy v razvytyy kardyovaskuliarnoi patolohyy [The role of hyperuricemia in development of the cardiovascular diseases]. Ukrainian journal of rheumatology. 2017; 2(68):38-46. (Ru)

3. Prasad Sah O.S., Qing Y.X. Associations Between HUA and Chronic Kidney Disease. A Review, Nephro-Urol Mon. 2015;7(3):e27233. doi: 10.5812/ numonthly.7(3)2015.27233.

4. 2018 ESC/ESH Guidelines for themanagement of arterial hypertension. The Task Force for the management of arterial hypertension of the European Society of Cardiology (ESC) and the European Society of Hypertension (ESH). European Heart Journal. 2018; 98. D01:10.1093/ eurheartj/ehy339

5. Rekomendatsii Asotsiatsii kardiolohiv Ukrainy z diahnostyky ta likuvannia khronichnoi sertsevoi nedostatnosti [Recommendations by the Association of cardiologists of Ukraine on chronic heart failure diagnostic and treatment]. Asotsiatsiia kardiolohiv Ukrainy, Ukrainska asotsiatsiia fakhivtsiv iz certsevoi nedostatnosti. Kyiv. 2017; 65. (UA)

6. Iwashima Y., Horio T., Kamide K. et al. Uric acid, left ventricular mass index, and risk of cardiovascular disease in essential hypertension. Hypertension. 2006;47:195-202.

7. Unifikovanyi klinichnyi protokol pervynnoi, ekstrenoi ta vtorynnoi medychnoi dopomohy «Arterialna hipertenziia» [Unified clinical protocol for primary, emergency and secondary care «Arterial hypertension»]. MOZ Ukrainy. 2016. (UA)
8. Pro zatverdzhennia ta vprovadzhennia medyko-tekhnolohichnykh dokumentiv zi standartyzatsii medychnoi dopomohy pry arterialnii hipertenzii [On approval and implementation of medical and technological documents on standardization of medical care in arterial hypertension]: Nakaz Ministerstva okhorony zdorov'ia vid 24.05.2012 №384. (UA)

9. Richette P., Doherty M., Pascual E. et al. 2016 updated EULAR evidencebased recommendations for the management of gout. Ann Rheum Dis. 2016; 10:1-14. doi:10.1136/annrheumdis-2016-209707

10. Mosteller R.D. Simplified calculation of body-surface area. N Engl J Med. 1987 0ct22;317(17):1098.Availablefrom:https:/www.nejm.org/doi/full/10.1056/ NEJM198710223171717 DOI: 10.1056/NEJM198710223171717

11. Fossati P., Prencipe L., Berti G. Use of 3,5-dichloro-2-hydroxybenzenesulfonicacid/4-aminophenazone chromogenic system in direct enzymic assay of uric acid in serum and urine. Clin Chem. 1980;26(2):227-231. Available from: 9ec2eeafe0c73b6f04c5c21db808206169fe.pdf

12. ASE committee recommendations. Recommendations for Chamber Quantification: A Reportfrom the American Society of Echocardiography's Guidelines and Standards Committee and the Chamber Quantification Writing Group, Developed in Conjunction with the European Association of Echocardiography, a Branch of the European Society of Cardiology. J Am Soc Echocardiogr. 2005;18(12):1440-63. Available from: https://www.onlinejase.com/article/S0894-7317(05)00983-1/pdf D0l: 10.1016/j.echo.2005.10.005

13. Ofori S.N., Akpa M. Relationship between uric acid and left ventricular mass and geometry in Nigerian patients with untreated essential hypertension. Nigerian Journal of Cardiology. 2015; 12(2):129-135.

Scientific research work: 01164004046 "Diseases of the internal organs: predictors of development, optimization, diagnosis, treatment and prevention».

\section{ORCID and contributionship:}

Olha M. Chernatska - 0000-0001-9093-6862 D,F

Liudmyla N. Prystupa - 0000-0002-6454-9831 ${ }^{\text {A }}$

Hanna A. Fadieieva - 0000-0003-3056-5793 ${ }^{C}$

Alina V. Liashenko - 0000-0002-7172-2858 ${ }^{B}$

Yuliia O. Smiianova - 0000-0002-8782-0559 ${ }^{E}$

\section{Conflict of interest:}

The Authors declare no conflict of interest

CORRESPONDING AUTHOR
Olha M. Chernatska
Sumy State University
Rymskoho-Korsakova St., 2, 40007, Sumy, Ukraine
tel: +380502089987
e-mail: chernatskaya@ukr.net

Received: 29.01 .2020

Accepted: 30.03 .2020

A - Work concept and design, B - Data collection and analysis, C - Responsibility for statistical analysis, D-Writing the article, E-Critical review, $\mathbf{F}$ - Final approval of the article 